\title{
ジオシンセティックス補強土壁の システム冗長性を考慮した信頼性解析法
}

\author{
宮田喜壽 1 ・篠田昌弘 ${ }^{2}$
}

\begin{abstract}
ジオシンセティックス補強土壁は冗長性の高い並列構造システムを有する。この種の構造システムでは，ひ とつの構造要素の破壊が構造物の全体破壞に容易につながらない，本論文は，ジオシンセティックス補強土壁 のシステム午長性を考慮した信頼性解析法を提案する．提案する解析法は，1層のジオシンセティックスが分 担する補強領域を構造要素と定義し，各構造要素の複合的な破壊が全体破壊につながるという考えに基づく． 本論文では，提案する解析法の特徴ならびに部分係数の決定法への応用について考察する.
\end{abstract}

キーワード : 補強土壁, ジオシンセティックス, 信頼性解析, 壳長性

\section{1.はじめに}

ジオシンセティックス補強土壁の設計法は，許容応力 度設計法から部分係数設計法に移行している. 部分係数 設計法では, 安全率に代わり, 荷重の余裕度を見積もる ための部分係数と耐力の余裕度を見積もるための部分係 数が用いられる. 英国の BS $8006^{1)}$, 北欧の Nordic Handbook $^{2)}$, そして香港の Geoguide $6^{3)}$ では, 部分係数を 荷重・材料パラメータの特性值に適用して設計值を求め, それを設計モデルに代入して限界状態の照査を行う（材 料係数アプローチ). 米国の AASHTO LRFD ${ }^{4)}$ では, 荷 重・材料パラメータの特性值をそのまま設計モデルに代 入して荷重・耐力の特性值を求め, 部分係数を荷重・耐 力の特性值に適用して限界状態を照査する（抵抗係数ア プローチ）。日本の鉄道補強土構造物の設計法 5゙では, 性能照査型設計の枠組みの中で, 抵抗係数アプローチの 部分係数設計法が採用されている. しかし，上記設計法 に示されている部分係数には，荷重・抵抗の統計的性質 や設計モデルの不確定性が十分に考慮されていない，そ の合理的な更新が課題とされているの.

部分係数設計法のフォーマットは信頼性理論をベース にしている. 荷重・耐力に関する部分係数は，構造物に 生じる各種限界状態をどの程度の頻度まで許容するかと いう許容破壊確率の関数で表すことができる》。破壊確 率はリスクやライフサイクルコストと容易に関連付ける ことができる. したがって, 部分係数設計法は, 構造物 の重要度に応じて設計レベルを合理的に変化させる設計 への適用性を有している. 建築の分野では，この考えが 実務でも普及し始め多大な効果を収め ${ }^{8)}$ ，土木の分野で もその検討が盛んになろうとしている. ジオシンセティ ックス補強十壁の破壊確率を計算するための信頼性解析

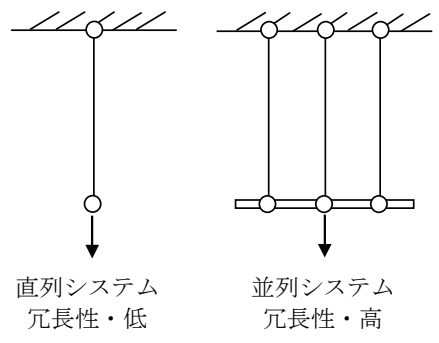

図-1＼cjkstart構造システムと冗長性

法を確立し，部分係数設計法の高度化を進める必要があ る.

信頼性解析法を確立する場合，対象とする構造物のシ ステム特性を十分に考慮する必要がある. 一般の構造物 のシステム特性は, 図-1 に示すような直列システム, 並列システム，あるいはその組み合わせとしてモデル化 できる. 直列システムでは, ひとつの構造要素の破壊が 構造物全体の破壊に直接的に結びつく. 並列システムで は，荷重の再分配が行われるので，両者の破壊は直接的 に結びつかない，その程度が大きいときほど，システム 圥長性が高いといわれる9 . ジオシンセティックス補強 土壁は, 盛土材, 多層配置されたジオシンセティックス, 壁面工で外力に抵抗する。このような構造システムは, 圥長性が高い並列システムとみな寸ことができる. しか し，ジオシンセティックス補強土壁の信頼性設計法に関 する既往の研究では, 安全率を用いる許容応力度設計法 との対比が重視されたため, 既存の設計式で評価される 安全率が 1 以下になる確率を破壊確率とするものが多か った ${ }^{10,11}$. そのような解析法で上述した構造システムを 合理的に評価することは難しい，新しい概念に基づく信 頼性解析法を確立する必要がある.

1正会員, 防衛大学校 建設環境工学科（广239-8686 横須賀市走水1-10-20）

2正会員，（財）鉄道総合技術研究所 構造物技術研究部 基礎・土構造（广185-8540 東京都国分寺市光町2-8-38） 
著者は，1層のジオシンセティックスが分担する補強 領域を構造要素と定義し, 各構造要素の複合的な破壊が 全体破壊につながるという考えをもとに，ジオシンセテ イックス補強土壁の信頼性解析法を確立した．本論文で は，その基本的な考え方を説明し，代表的な設計条件に 対する解析結果を示寸. そして，その解析法を部分係数 の決定に応用寸る方法について考察する．なお，先に述 べたように, 部分係数設計法には, 材料係数アプローチ と耐力係数アプローチが存在する. 本文では, 耐力係数 アプローチの部分係数設計法を前提に議論する. また, 圥長性という用語は, 無駄の大きさを表す指数として用 いられる場合もある。本文では，一部に破壊があっても 構造全体としては所定の要求機能を果たし続ける性質を 表す用語として用いる。

\section{2. 解析法}

\section{（1）部分係数設計法の基本的な考え}

耐力係数アプローチの部分係数設計法では，各限界状 態に対して以下の基本式で構造物の安定性を照査する.

$$
\phi \mathbf{R}>\gamma \mathbf{Q}
$$

ここで, $\mathbf{R}$ : 耐力の公称值, $\mathbf{Q}$ : 荷重の基本值， $\phi$ : 耐力 係数, $\gamma$ : 荷重係数である. $\phi$ と $\gamma$ は, 目標信頼性, 荷 重・耐力の統計的性質, 設計モデルの不確実性の関数で ある. 荷重・耐力の統計的な性質を正規分布と仮定寸る と，両者は以下の近似式で表される ${ }^{12)}$.

$$
\begin{aligned}
& \phi=\mu_{\mathrm{R}}\left(1-\alpha \beta_{\mathrm{T}} \operatorname{COV}_{\mathrm{R}}\right) \\
& \gamma=\mu_{\mathrm{Q}}\left(1+\alpha \beta_{\mathrm{T}} \operatorname{COV}_{\mathrm{Q}}\right)
\end{aligned}
$$

ここで， $\alpha$ : 感度係数, $\beta_{\Gamma}$ : 目標信頼性指標, $\mu_{\mathrm{Q}}, \mu_{\mathrm{R}}$ : 荷重および耐力モデルに関する bias の平均值, $\mathrm{COV}_{\mathrm{Q}}$, $\mathrm{COV}_{\mathrm{R}}$ : 荷重および耐力モデルに関する bias の変動係数 である. bias は次式で定義されるモデルの確からしさを 示寸指標である.

$$
\text { bias }=\frac{\text { 荷重 or 耐力の実測值 }}{\text { 荷重 or 耐力の予測值 }}
$$

$\alpha$ は実データを用いた感度解析より決定される. $\beta_{\mathrm{T}}$ は, 許容される構造物の破壊確率 $P_{\mathrm{f}}$ 之確率分布関数で一義 的に関係づけられる，以下では，まず本論文の対象とす る限界状態を明確にし, システム冗長性を考慮した信頼 性解析法について論じる.

\section{（2）本論文の対象とする限界状態と設計モデル}

本研究では，はじめに補強材の破断を伴う内的安定性 の照査に対して信頼性設計法の枠組みを確立し，その方 法を，他の破壊モ一ド，地震時などの荷重条件，一般的 な確率分布の問題に拡張するという計画で検討を行って いる. 本論文では, 補強材に作用寸る引張り力が材料強 度に達し, 補強領域が全体破壊するという終局限界状態 を対象にする. 荷重は常時荷重のみを考慮する．信頼性 解析では，式(2)，(3)に示したように，bias の統計解析と モデルの適切化に関する検討も重要になる ${ }^{13)}$. 本論文で は，荷重・耐力の推定法として，現行の設計モデルを用 い，一連の計算では便宜上，式(4)で定義した bias の平均 值をともに 1 と仮定する．このように考えると，本論文 の対象とする問題は以下のように表される.

$$
\begin{gathered}
\phi T_{\mathrm{ult}}>\gamma T_{\text {max }} \\
\phi=1-\alpha \beta_{\mathrm{T}} \sigma_{\text {Tult }} \\
\gamma=1+\alpha \beta_{\mathrm{T}} \sigma_{\mathrm{T} \max }
\end{gathered}
$$

ここで, $T_{\text {ult }}$ : 補強材の引張り強度の公称值, $\sigma_{\text {Tult }}: T_{\text {ult }}$ の標準偏差, $T_{\max }$ : 補強材に作用寸る引張り力の基本值, $\sigma_{\text {Imax }}: T_{\max }$ の標準偏差である.

式(6)，(7)において，設定が最も難しいのが $\beta_{\mathrm{T}}$ の設定 である。一般的な地盤設計では，破壊確率 $P_{\mathrm{f}}=0.001$ に 相当する $\beta_{\mathrm{T}}=3.09$ を仮定するのが一般的である ${ }^{14}$. 杭基 礎に関する地盤設計では，杭基礎が冗長性の高い並列シ ステムであることを考慮し，許容破壊確率 $P_{\mathrm{f}}=0.01$ に相 当する $\beta_{\mathrm{T}}=2.33$ が仮定される ${ }^{15,10}$. Bathurst et al. ${ }^{177}$ は, 補 強土壁の信頼性設計法における一連の検討において, 補 強土壁が咒長性の高い並列システムを有していることを ふまえ，杭基礎に関する設計と同じく $\beta_{\mathrm{T}}=2.33$ を仮定し ている，米澤ら ${ }^{18} /$ は，鉄道補強土壁構造物のキャリブレ ーション結果より, 滑動モードで $\beta_{\mathrm{T}}=2.62$, 転倒モード で $\beta_{\mathrm{T}}=3.51$ を示している. しかし，既往の研究において， 補強土壁の構造システムを考慮した合理的な $\beta_{\mathrm{T}}$ の算定 法は確立されていない. ジオシンセティックス補強土壁

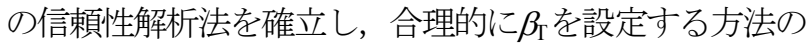
確立が強く望まれている.

\section{（3）補強土壁の冗長性を考慮した信頼性解析法}

ジオシンセティックス補強土壁が並列システムとして モデル化できることは先に述べた．並列システムの信頼 性を厳密に解くことは非常に難しい. 破壊確率の大きさ を上下界值で挟み込む解析法が提案されているが 19, 20), 上下界值の幅は非現実的なほど大きくなる，また，その 解析法は, 構造要素の破壊と荷重再分配を繰り返しなが ら崩壞に至るシステム冗長性の効果を合理的に評価でき ない ${ }^{21)}$. 本論文では，実務的に最も問題になる破壊の進 展経路のみを考慮し, システム冗長性を考慮したジオシ ンセティックス補強土壁の信頼性解析法を提案する.

提案寸る解析法では，図-2 に示寸ような破壊の進展 経路を仮定する．1層のジオシンセティックスが分担す る補強領域を構造要素と定義し, 各構造要素の複合的な 破壊が全体破壞につながると考える，具体的には，破壊 がのり先から進展すると仮定し，ジオシンセティックス の破断と荷重の再配分が繰り返されることで, 補強領域 が全体破壊に至るという破壊モードを仮定する，荷重の 再分配の解析法については, 下から i 番目のジオシンセ ティックスに破断が生じたとき，その一段上の $\mathrm{i}+1$ 番目 のジオシンセティックスが $\mathrm{i}$ 番目のジオシンセティック 

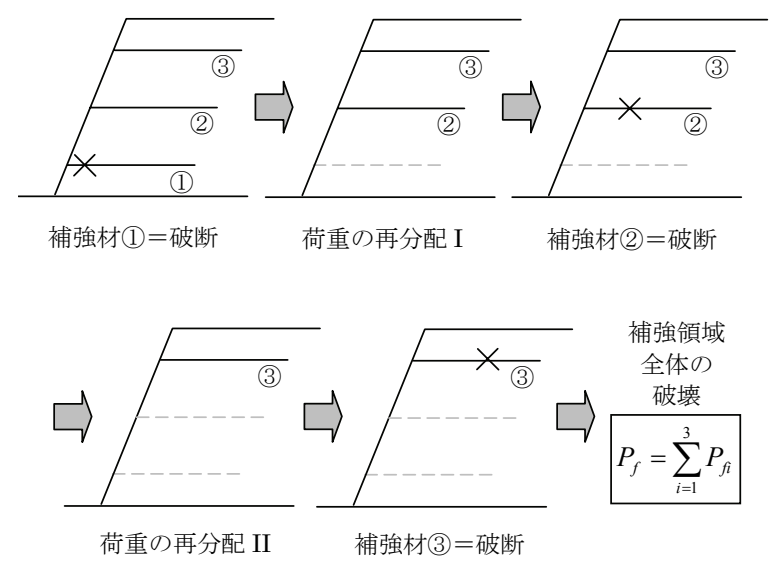

図-2 システム攵長性を考慮した信頼性解析法

スが受け持っていた荷重を分担すると仮定する.この仮 定は最も単純なものとして採用した。 その妥当性につい て今後の検討が必要である.

以上述べた仮定に基づくと，構造要素の破壊確率 $P_{\mathrm{fi}}$ は次式で評価できる.

$$
P_{\mathrm{fi}}=\Phi\left(\beta_{\mathrm{i}}\right)
$$

ここで, $\mathrm{i}:$ 構造要素番号, $\beta_{\mathrm{i}}: \mathrm{i}$ 番目の構造要素の信頼 性指標である. $\beta_{\mathrm{i}}$ は次式で定義される.

$$
\beta_{\mathrm{i}}=\frac{\mu_{\mathrm{Tult}}(t)-\mu_{\mathrm{Tmax}}}{\sqrt{\sigma_{\mathrm{Tult}}^{2}+\sigma_{\mathrm{T} \max }^{2}}}
$$

ここで, $\mu_{\text {Tult }}(t)$ : 所定の供用時間 $t$ におけるジオシンセ ティックスの引張り強度 $T_{\mathrm{ult}}(t)$ の期待值, $\sigma_{\text {Tult }}: T_{\mathrm{ult}}(t)$ の 分散, $\mu_{\mathrm{T} \max }(t)$ : ジオシンセティックスに作用する引張り 力 : $T_{\max }$ の期待値, $\sigma_{\mathrm{T} \text { max }}$ は $T_{\max }$ の分散である. 補強領域 全体の破壊は各構造要素の破壊の積事象として捉えられ るので，その生起確率は式(8)で定義した構造要素の破 壊確率を用いて次式で表される。

$$
P_{f}=\sum_{i=1}^{3} P_{f i}
$$

式(8)で破壊確率を計算する場合， $\mu_{\text {Tult }}(t), \mu_{\text {Tmax }}(t)$, $\sigma_{\text {Tult }}, \sigma_{\text {Tmax }}$ のモデルが必要になる. それらの解析法に ついて以下に述べる.

$\mu_{\text {Tuth }}(t)$ にいては，その值がジオシンセティックスの クリープ破断強度一載荷時間関係をもとに評価できると 仮定し，次式のモデルで計算する。

$$
\mu_{\text {Tult }}(t)=T_{0}-\lambda \log t
$$

ここで， $T_{0}$ は未使用時のジオシンセティックスの引張り 強度であり，入は定数である. 現行のクリープ破断に関 する材料安全係数 $F_{\mathrm{cr}}$ が 100 年後の破断強度を保障して いると理解すると, $\mu_{\text {Tult }}(t=100)=T_{0} / F_{\mathrm{cr}}$ より, 定数 $\lambda$ は 次式で表現される.

$$
\lambda=\frac{1}{2}\left(1-\frac{1}{F_{\mathrm{cr}}}\right)
$$

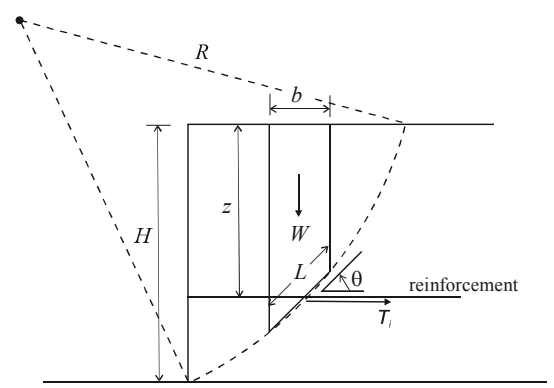

図-3＼cjkstart補強材に作用寸る引張り力の算定モデル

$\mu_{\operatorname{Tmax}}(t)$ については，現行の土研マニュアルの設計モデ ル22)が適用できると仮定し，次式のモデルを用いる.

$$
\mu_{\text {Tmax }}(t)=K \sigma_{v}
$$

ここで， $K$ : 土圧係数， $\sigma_{\mathrm{v}}$ : ジオシンセティックスが敷 設されている面に作用する鉛直土圧である． $K$ : は以下 の最適化計算より求める.

$$
K=\frac{2 \sum T_{\text {req }}}{\gamma H^{2}}
$$

$$
\sum T_{\text {req }}=\max \frac{F_{\mathrm{s}} \sum W \sin \alpha-\sum W \cos \alpha \tan \phi_{\mathrm{s}}}{\sum\left\{\frac{2}{H^{2}} z b \tan \theta\left(\cos \theta+\sin \theta \tan \phi_{\mathrm{s}}\right)\right\}}
$$

$\phi$ 㳑土材の内部摩擦角， $F_{\mathrm{s}}$ は必要安全率である．本論 文ではマニュアルで奨励されている $F_{\mathrm{s}}=1.0$ を仮定する. 式(15)中の各係数の意味は図-3に示した.


り強度, それに作用する荷重の統計的な性質についてエ ルゴード性を仮定し，時間的に変化しないと仮定する.

\section{3. 解析結果と考察}

\section{（1）解析条件}

高さ6.0m，勾配1 : 03のジオシンセティックス補強土壁 を内部摩擦角 : $\phi_{s}=35 \mathrm{deg} の$ 盛土材, 未使用時の引張り強 度 : $T_{0}=40 \mathrm{kN} / \mathrm{m}$, クリープ低減係数 $F_{\mathrm{cr}}=1.5$ のジオシンセ ティックスで構築する場合を想定し，図-4に示すような 敷設条件を解析ケースとした。一連の解析では，供用年 数100年まで計算を行った.

解析では，まず盛土材とジオシンセティックスのばら つきに関するパラメータを固定し，ジオシンセティック スの引張り強度 : $T_{0}$, 盛土材の摩擦角 : $\phi_{s}$, そしてジオ シンセティックスのクリープに関する材料安全率 : $F_{\mathrm{cr}}$ が, 補強領域の内的破壊確率：P $P_{\mathrm{f}}$ 及ぼす影響を調べた。 そ の後, 盛土材とジオシンセティックスのばらつきの大き さが $P_{\mathrm{f}}$ 及ぼす影響を調べた。 そして，それらの解析結 果をもとに，式(6)，(7)に示した部分係数の算定に必要 な目標信頼性指標 : $\beta_{\mathrm{T}}$ の設定法について検討した. 


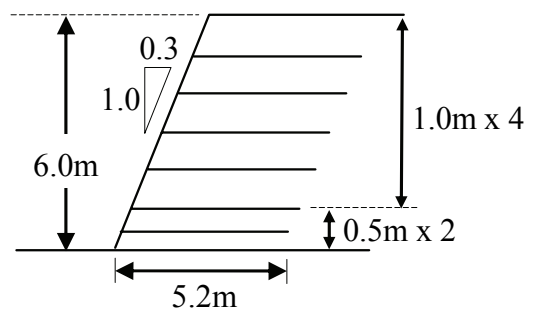

図-4 解析で仮定した敷設条件

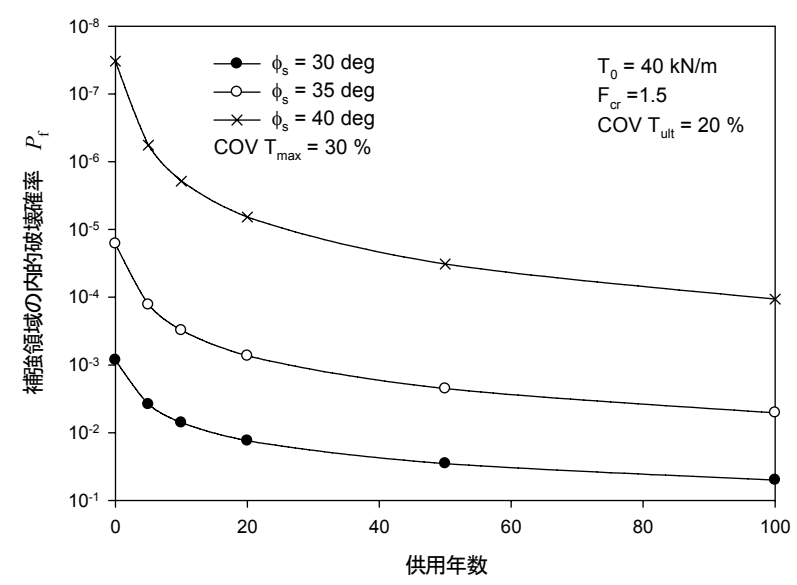

図-5＼cjkstart盛土材の摩擦角が破壊確率に及ぼす影響

\section{（2）各種条件が破壊確率に及ぼす影響}

盛土材の摩擦角が $P_{\mathrm{f}}$ 及ぼす影響を調べた解析結果を 図-5に示す．解析では，盛土材の内部摩擦角 $\phi_{s}$, $\phi_{s}=$ 30, 35, 40deg と変化させて計算した. その他の解析条件は 図中に示すとおりである. 姑が大きくなると, 補強材に 作用する引張り力が小さくなるので， $P_{\mathrm{f}}$ が小さくなる. また，供用時間が長いときほど，クリープ破断強度が小 さくなるので, $P_{\mathrm{f}}$ は大きくなる.

ジオシンセティックスの引張り強度が補強領域の全体 破壊確率：P $P_{\mathrm{f}}$ 及ぼす影響を調べた解析結果を図-6に示 す. 解析では, ジオシンセティックスの未使用時の引張 り強度 : $T_{0}$ を, $T_{0}=30,40,50 \mathrm{kN} / \mathrm{m}$ と変化させて計算した。 その他の解析条件は図中に示すとおりである， $T_{0}$ が大き いときほど，安全に対する余裕度が大きくなるので， $P_{\mathrm{f}}$ が小さくなる。 また，供用時間が長いときほど，クリー プ破断強度が小さくなるので，P $P_{\mathrm{f}}$ は大きくなる.

ジオシンセティックスのクリープ破断に関する材料安 全係数が $P_{\mathrm{f}}$ 及ぼす影響を調べた解析結果を図-7に示す。 解析では，クリープ破断に関する材料安全率: $F_{\mathrm{cr}}$ を, $F_{\mathrm{cr}}$ $=1.0,1.2,1.5$ と変化させて計算した. その他の解析条件は 図中に示すとおりである. 供用年数が長くなると, クリ 一プ破断強度が小さくなるので， $P_{\mathrm{f}}$ 大゙きくなる．許容 年数100年の破壊確率で比較すると, クリープに関する 材料安全率が $0.2 \sim 0.3$ 程度で， $P_{\mathrm{f}}$ が 1 桁変わる程度の感度 である。

盛土材とジオシンセティックスのばらつきの程度が $P_{\mathrm{f}}$ に及ぼす影響を調べた解析結果を図-8，9に示す．今回 設定した条件では，ジオシンセティックスの引張り強度

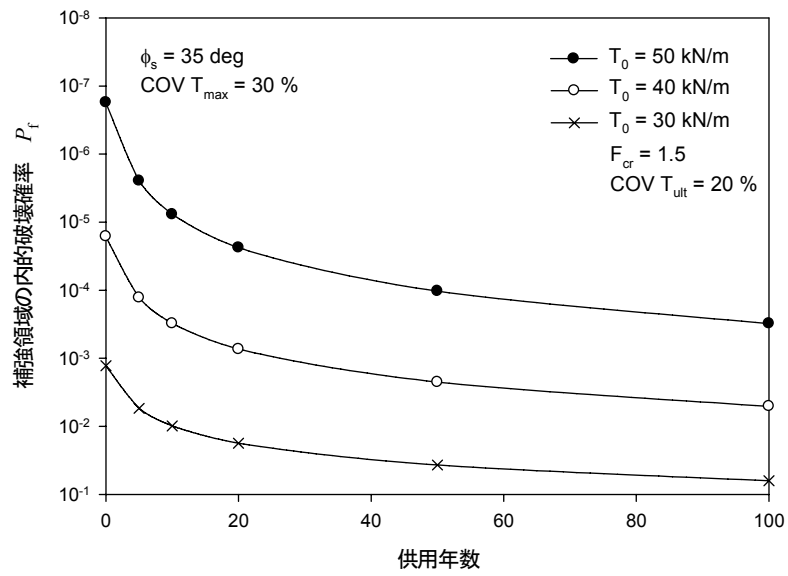

図-6＼cjkstart補強材の引張り強度が破壊確率に及ぼす影響

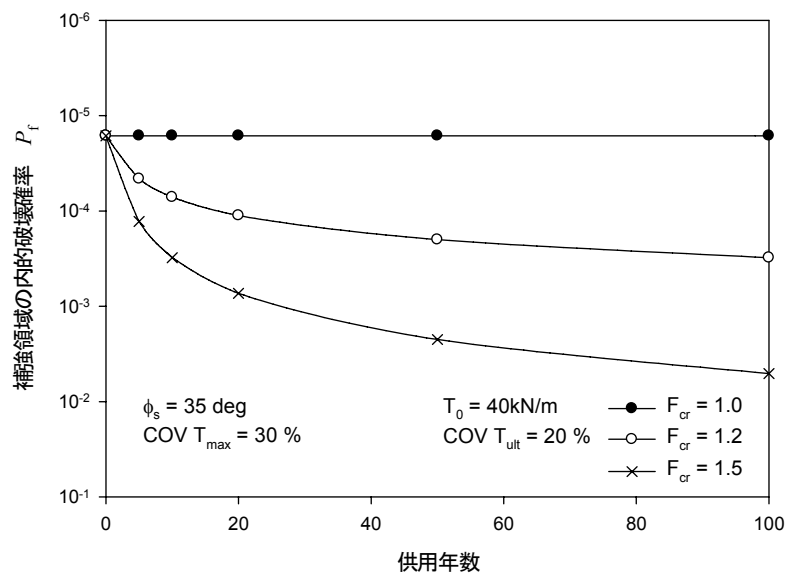

図-7補強材のクリープ安全率が破壊確率に及ぼす影響

に関するばらつきの感度の方が高い. ジオシンセティッ クスの引張り強度の変動係数が $10 \%$ 程度大きくなると, 計算される破壊確率が10倍近く大きくなる.

\section{（3）部分係数の算定への応用}

本論文で提案する解析法で計算される補強領域の内的 破壊確率： $P_{\mathrm{f}}$ ， 全構造要素に破壊が生じていない条件 での構造要素の信頼性指標： $\beta_{\text {local }}$ とを関連付けることが できれば，ジオシンセティックス補強士壁のシステム冗 長性を考慮した部分係数の設定が可能になる. そこで, 本章(2)に示した計算条件に対し，両者を関係付ける試 みを行った。計算例を図-10に示す。盛土材の内部摩擦 角 : $\phi_{s}=35 \mathrm{deg}$, 未使用時の引張り強度 : $T_{0}=40 \mathrm{kN} / \mathrm{m}$, ク リープ低減係数 $F_{\mathrm{cr}}=1.5$ の条件で, 盛土材とジオシンセテ イックスの強度のばらつきに関する条件を9パターン変 化させて計算を行った結果である. 図-4に示したように 6層のジオシンセティックスが敷設している条件を仮定 しているので，各計算条件に対し， $P_{\mathrm{f}}$ 6つの $\beta_{\text {local }}$ が計算 される. ジオシンセティックスの敷設位置によって作用 する引張り力と材料の引張り強度の相対的な関係が異な るので， $\beta_{\text {local }}$ 幅広く分布する. 設計では全ての構造要 素が所定の安全性を確保することを照査するから，ここ 




図-8 盛土材の強度のばらつきが破壊確率に及ぼす影響

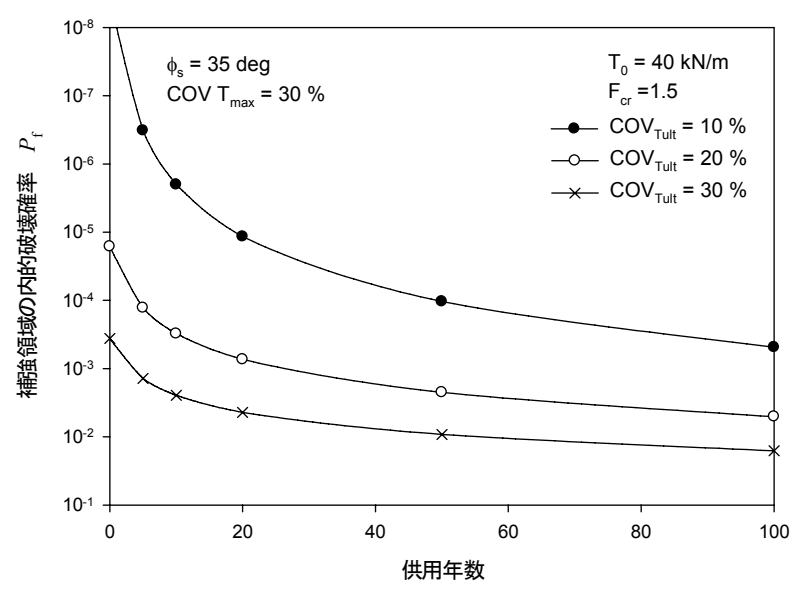

図-9＼cjkstart補強材の強度のばらつきが破壊確率に及ぼす影響

では $\beta_{\text {bcal }}$ の最小值min $\beta_{\text {bcal }}$ (構造要素の最小信頼性指標) に着目寸る。このmin $\beta_{\text {local }}$ 之補強領域の全体破壊確率か ら逆算で求めた信頼性指標 $\beta_{\mathrm{f}}$ との関係を図-11に示す. 両者の関係は幅広い条件に対して線形とみなせ，以下の 式で近似できる.

$$
\min \beta_{\text {local }}=m \beta_{\mathrm{f}}
$$

ここで， $m$ : 比例定数である. $m=1$, 寸なわち，構造全 体と構造要素とで信頼性が等しいときは, 構造システム が冗長性を有しないことを表す， $m$ が小さいときほど， 構造システムの圥長性が高いことを表す。今回の計算の 場合, $m=0.82$ であり, 今回提案する解析法によって, 図-4 に示したジオシンセティックス補強土壁のシステ ム冗長性を定量的に評価することができた.

式(16)の関係を用いれば，許容破壊確率と目標信頼性 指標とを容易に計算できる，すなわち，所定の許容破壊 確率に対し，正規確率関数を用いて目標信頼性指標 $\beta_{\mathrm{f}}$ を 計算し，その值を $m$ 倍したものが，所定の構造条件に 対する目標信頼性指標 $\beta_{\mathrm{T}}$ ということになる．図中には, システム冗長性を考慮しない $m=1$ のときの結果と, 図一 11 に示した結果より計算した結果とを示した。これに より，許容破壊確率を $10^{-3}$ としたときの目標信頼性指標

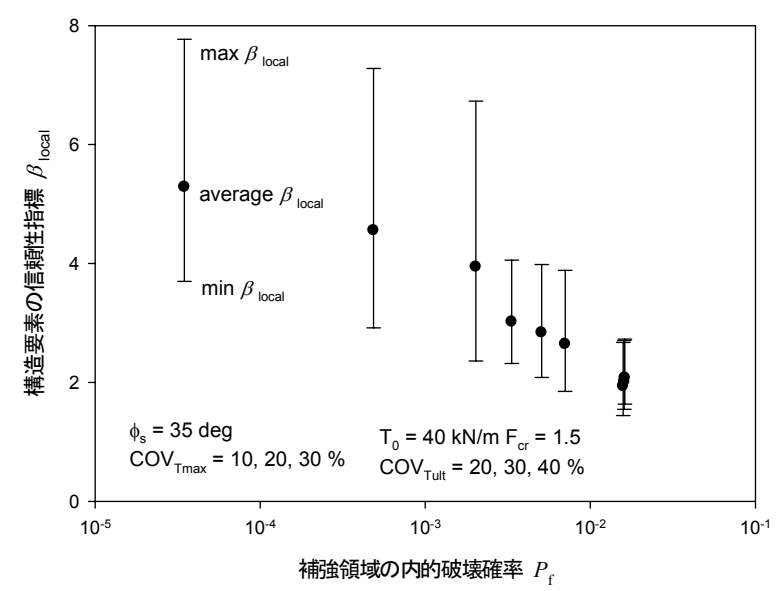

図-10 構造要素の信頼性指標と全体の破壊確率の一例

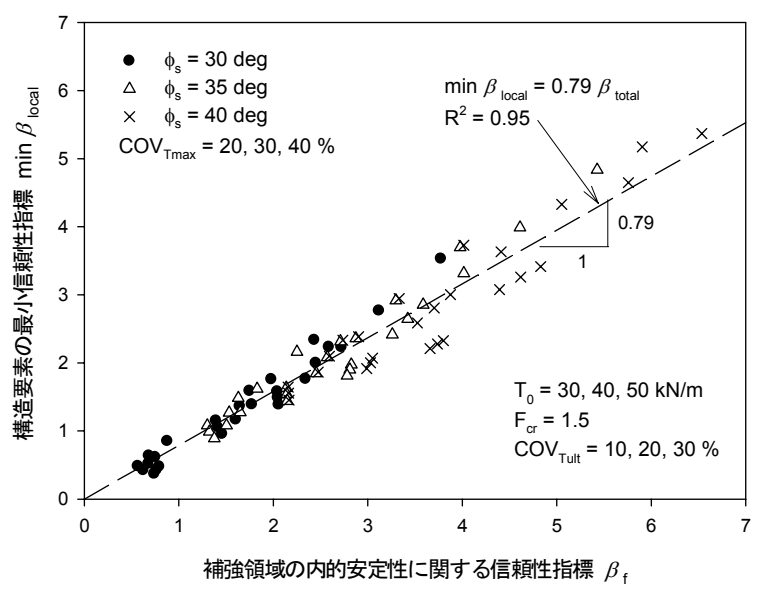

図-11 構造要素における信頼性指標と全体の破壊確率

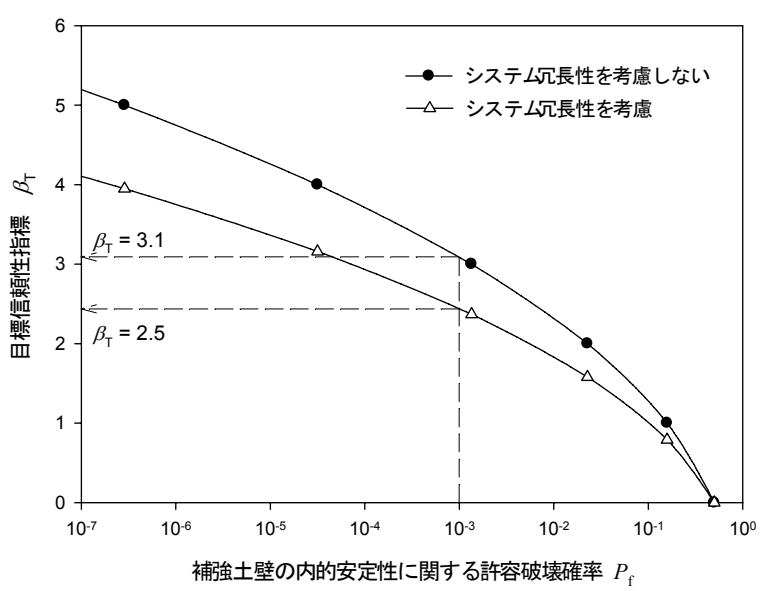

図-12 構造要素における信頼性指標と全体の破壊確率

は，システム圥長性を考慮すると， $\beta_{\mathrm{T}}=2.5$ 程度という ことになる.この值は，杭基礎や補強土壁の構造物のコ ードキャリブレーションで便宜的に用いられている值と ほぼ同じである，今後，様々な敷設条件に対して同様な 計算を実施し，一般的なジオシンセティックス補強土壁 のシステム冗長性を式(16)における係数 $m$ で表現すうる 
妥当性について検討をする必要がある.

\section{4. まとめ}

本論文において，ジオシンセティックス補強土壁のシ ステム冗長性を考慮した信頼性解析法を提案した。解析 結果を示し，提案法の有效性を示した. そして，その解 析を応用した目標信頼性指標の評価法を示した. 今後, この解析法を他の破壊モード，地震時などの荷重条件， 一般的な確率分布の問題に拡張する予定である.

\section{謝辞}

本研究は文部科学省科学研究費補助金基盤研究 (B)21360229（研究代表者 宮田喜壽）の助成を受けた.

\section{参考文献}

1) British Standards Institution (BSI): Code of practice for Strengthened / reinforced soils and other fills, 1995.

2) Geotechnical Engineering Office, Hong Kong, China: Geoguide 6. Guide to reinforced fill structure and slope design, 2003.

3) Nordic Geosynthetics Group (NGG): Nordic Handbook-Reinforced Soils and Fills, 2003.

4) American Association of State Highway and Transportation Official (AASHTO): Section 11 Abutments, Pies, and Walls, AASHTO LRFD Bridge Design Specifications SI units, 2007.

5) 鉄道総合技術研究所編, 国土交通省鉄道局監修 : 鉄道構造 物等設計標準・同解説: 土構造物，SI 単位版，2007.

6) 例えば, Allen, T.M., Nowak, A.S. and Bathurst, R.J.: Calibration to Determine Load and Resistance Factors for Geotechnical and Structural Design, Transportation Research Board Circular, E-C079, 93 p., 2005.

7) 例えば, Ditlevsen, O. and Madsen, H.O.: Structural reliability method, John Wiley \& Sons, 372p, 1996.

8) 神田 順 : 若き建築構造技術者に向けて一限界状態設計法の 挑戦，建築技術，191p，2004.

9) Hoshiya, M: Reliability of Redundant Cable System, J. of the Structural Division, ASCE, 97-ST11,2773-2776, 1971.
10) 宮田喜壽, 重久伸一, 木暮敬二 : ジオグリッド補強土壁の 信頼性解析に関する基礎的研究，ジオシンセティックス論 文集，15，235-245，2000.

11) Sayed, S., Dodagoudar, G. R. and Rajagopal, K. Reliability analysis of reinforced soil walls under static and seismic forces, Geosynthetics International, 15-4, 246-257, 2008.

12) Novak, A.S. and Collins, K.R.: Reliability of structures, McGrawHill, 338p, 2000.

13) Miyata, Y. and Bathurst, R.J.: Development of K-Stiffness method for geosynthetic Reinforced soil walls constructed with c- $\phi$ soils, Canadian Geotechnical Journal,44, 1391-1416, 2007.

14) Withiam, J.L., Voytko, E.P., Barker, R.M., Duncan, J.M., Kelly, B.C., Musser, S.C., and Elias, V.: Load and resistance factor design (LRFD) for highway bridge substructures. Report FHWA HI-98-032, Federal Highway Administration, 1998.

15) D'Appolonia Engineering: Developing new AASHTO LRFD specifications for retaining walls, Report for NCHRP Project 20-7, Task 88, Transportation Research Board, 63p, 1999.

16) Paikowsky, S.G.: Load and resistance factor design (LRFD) for deep foundations. NCHRP Report 507, National Cooperative Highway Research Program, Transportation Research Board of the National Academies, 126p, 2004.

17) Bathurst, R.J., Allen, T.M. and Nowak, A.S.: Calibration concepts for load and resistance factor design (LRFD) of reinforced soil walls, Canadian Geotechnical Journal, 45, 1377-1392, 2008.

18) 米澤豊司, 篠田昌弘, 舘山勝, 古関潤一 : 補強土壁構造物 の限界状態設計法における荷重係数と抵抗係数，土大学会 論文集，785III-52,71-81,2005.

19) Ang, A.H.S., Tang, W.H.: Probability Concepts in Engineering Planning and Design, John Wiley \& Sons, 562p, 1984.

20) Ditlevsen O.: Narrow reliability bounds for structural systems, Journal of structural mechanics, 7-4,453-472, 1979.

21）星谷 勝, 山本欣弥: 情報エントロピーを用いたシステム の信頼性と圥長性の検討，土大学会論文集，654 I-52, 355$366,2000$.

22) 土木研究センター：ジオテキスタイルを用いた補強土の設 計・施工マニュアル 改訂版, 305p., 2000.

\title{
RELIABILITY ANALYSIS METHOD OF REDUNDANT GEOSYNTHETIC-REINFORCED SOIL WALLS
}

\author{
Yoshihisa MIYATA and Masahiro SHINODA
}

Geosynthetic-reinforced soil walls have system redundant parallel structural system. In this case, failure of one structural component does not lead to collapse of structural system. This paper proposes new reliability analysis method for redundant geosynthetic-reinforced soil walls. Proposed analysis method is based on basic concept that failure of geosynthetic-reinforced soil wall is multiple. In this paper, outline of the analysis method is explained. Estimation method of partial safety factors with considering redundant structural system is also discussed.

Keyword: reinforced soil walls, geosynthetics, reliability analysis, redundancy 